\title{
The timing and evolution of the post-glacial transgression across the Sea of Marmara shelf south of Istanbul
}

\author{
K. Eris ${ }^{a}{ }^{*}$, W.B.F Ryan ${ }^{b}$, M.N. Çağatay ${ }^{a}$, U. Sancar ${ }^{a}$, G. Lericolais ${ }^{c}$, G. Ménot ${ }^{d}$, E. Bard ${ }^{d}$
}

\author{
a'stanbul Technical University Faculty Of Mines, Emcol, Geology Department Ayazağa, İstanbul Turkey \\ ${ }^{b}$ Lamont-Doherty Earth Observatory of Columbia University, Palisades, NY, USA \\ 'Laboratoire de Environnements Sedimentaires, IFREMER, France \\ ${ }^{\mathrm{d}}$ Collège de France, CEREGE, UMR-6635, France
}

*: Corresponding author : Eris K. email address : keris@itu.edu.tr

\begin{abstract}
:
High-resolution reflection seismic profiles with core analyses of sedimentary sequence near the Sea of Marmara (SoM) entrance to the Strait of İstanbul (Sol, Bosphorus) provide detailed record of sealevel changes since the Late Glacial Maximum (LGM). The sequence is deposited over the LGM erosional surface at a maximum depth of $-105 \mathrm{~m}$. It includes seven seismic units that can be confidently correlated with 14C-dated sedimentary units in the cores. Unit 6 represents levee deposits of the paleo-Sol channel that was deposited by a Black Sea outflow during 11.2-10.6 kyr BP. The reflection surfaces at base of Unit 5 and 4 correspond to wave-cut terraces at -71and -63 m, respectively, and are estimated to be 10.6 and $9.8 \mathrm{kyr}$ BP. The seismic Unit 2, overlaying a mud drape (Unit 3), comprises deltaic sediments that was deposited during 6.400-3200 yr 14C BP. Isopach map and forset directions of the deltaic unit indicates that the delta was sourced from Kurbağalıdere River. Depositional period of the delta is subdivided into two stages in response to changes in the 49 balance between sealevel change and sediment supply rates: a progradational and an aggradational stages. The progradational stage prevailed during 6.4-4.7 kyr BP when the sealevel rise decelerated and there was a high sediment input from the drainage area of the Kurbağalıdere River. An aggradational stage developed during 4.7-3.2 kyr BP and indicates that the delta grew during faster sealevel rise when the rate of sediment input was relatively decreased. The onset of delta deposition at $6.4 \mathrm{kyr} \mathrm{BP}$ is marked in the SoM by termination of the early Holocene Sapropel deposition and the aggradational stage overlaps with the late Holocene Sapropelic unit deposited on the shelf areas. Our finding contradicts the hypothesis of Hiscott et al. (2002) and Aksu et al. (2002) that this delta was sourced from the Black Sea and that it indicates a persistant Black Sea outflow since $10 \mathrm{kyr}$ BP.
\end{abstract}

Keywords: seismic stratigraphy; sealevel; Holocene; Marmara Sea; delta; sapropel 


\section{1. INTRODUCTION}

65 The Sea of Marmara (SoM) is a $210 \mathrm{~km}$ long and $75 \mathrm{~km}$ wide intracontinental sea on 66 the gateway between the Mediterrenean Sea and the Black Sea (Fig. 1). It is connected to the 67 low salinity ( $\mathrm{S}=18 \%$ ) Black Sea via the Strait of Istanbul (SoI, Bosphorus) and to the marine 68 (S=38\%) Aegean Sea via the Çanakkale Strait (Dardanelles), having sill depths of -35 and $6975 \mathrm{~m}$, respectively. The shelf break in the SoM occurs at 90 m water depth. The Sol's 70 channel connects with a prominent submarine canyon dissecting the SoM shelf (Fig. 2). 71

72 During the late glacial sealevel lowstand, the SoM was isolated from the 73 Mediterranean Sea and it was a fresh to brackish water lake, as indicated by the presence of 
74 the Neoeuxinian fauna in the SoM (Çagatay et al., 2000). With the rise of the sealevel as a 75 result of deglaciation, Mediterranean marine waters flooded the SoM at ca. $12 \mathrm{kyr}$ BP 76 (Çağatay et al., 2000). Following this marine connection, the sealevel continued to increase in 77 the SoM, in tandem with the global sealevel. During the Younger Dryas (YD) there was a 78 sealevel still stand at $-65 \mathrm{~m}$ in the SoM, as evidenced by a prominent palaeoshoreline and 79 erosional terrace over the Marmara shelves (Çağatay et al., 2003). Global ocean level 80 increased further during the Climatic Optimum starting at 10.5 cal. kyr BP (Derijk et al., 81 1999). The Mediterranean waters from the SoM eventually flooded the Black Sea through the 82 SoI after breaching of the strait's sill at $8.4 \mathrm{kyr}$ BP (Ryan et al., 2003; Major et al., 2002, 83 2004).

84 Two Holocene deltas are present on the both sides of the SoI on northern shelf of the 85 SoM (Fig.1). The one west of the SoI, is clearly sourced from the Ayamama River (Kurt, 86 1994) (Fig.1c); whereas the sediment source and timing of deposition for the other delta near 87 the SoM entrance of the SoI (Fig. 1d), close to the mouth of Kurbagalidere River, is 88 controversial. The latter delta has been studied by different workers to test the "catastrophic 89 Black Sea flooding at 7.2 kyr BP” hypothesis of Ryan et al. (1997). Hiscott et al. (2002) and 90 Aksu et al. (2002) proposed that the delta was constructed during 10-9 kyr BP by a Black Sea 91 outflow that persisted to the present. However, Major et al. (2002) and Ryan et al. (2003) 92 using isotope, seismic and bathymetric data concluded that the Black Sea outflow through SoI 93 occurred during the Younger Dryas (YD), which was followed by a drop in the level of the 94 Black Sea from $-35 \mathrm{~m}$ to $-95 \mathrm{~m}$. The same delta was also studied by Oktay et al. (2002) and 95 Gökaşan et al. (2005) who concluded that it was sourced from the Kurbagalıdere River, rather 96 than by the SoI and deposited during 11-10 kyr BP. 
In this study, we present detailed seismic stratigraphic analysis of high resolution shallow seismic lines crossing an area near the southern entrance of SoI, together with the

100 core stratigraphy. Our objectives are to discuss the chronostratigraphic evolution of the

101 Holocene sediments including delta formation in the paleo-SoI channel, and shed light on the 102 water exchange problem between the Marmara and the Black Seas during the Holocene.

\section{METHODS OF SEISMIC DATA ACQUISTION AND ANALYSIS}

The high-resolution profiles were obtained during two cruises of the Department of Navigation, Hydrography and Oceanography (SHOD) R/V Çubuklu in 1993 and 1997 (Fig.

2). The sparker data were recorded directly on paper and covered approximately the top 100 $\mathrm{m}$ of the subsurface. Positioning was provided by Trisponder (using three shore-based radio beacons) with an accuracy of about $10 \mathrm{~m}$. Depths of reflectors were estimated using average water and sediment velocities of 1500 and $1700 \mathrm{~m} \cdot \mathrm{s}^{-1}$, respectively. The present day

111 bathymetric map of the southern enterance was created by using seismic profiles and 112 additional SHOD data (Fig. 2). Two gravity cores were recovered onboard R/V MTA Sismik-

1131 in 2003 and R/V Marion Dufresne in 2004. Core TSU03-13 (40 57' 20/ 29 00' 09) is

114 located on the top of the delta at $37 \mathrm{~m}$ water depth on the eastern part of seismic profile $\mathrm{K} 3$

115 (Fig. 2). Core MD-2750 (40 56 70/28 56 15) is located in the submarine channel of the SoI 116 at $68 \mathrm{~m}$ water depth on the seismic profile K4 (Figs. 2 and 3).

The ages of reflectors A and B marking the termination and onset of the delta were

120 carefully cleaned to remove any coatings, and then studied under microscope to ensure that 121 they were diagenetically unaltered. The radiocarbon analysis was carried out at the University 122 of Arizona (Lab. Number A-13668) and Woodshole NOSAMS facility (Lab. Number OS- 
123 50130, OS-50131 and OS-53538). The ages were calculated as yr BP, corrected for ${ }^{13} \mathrm{C}$, and

124 errors are expressed as $+/-1 \sigma$. The ${ }^{14} \mathrm{C}$ ages are not corrected for the reservoir age and not 125 calibrated. Organ ic carbon (Corg) was analysed by the Walkey-Balke method (Gaudette et al., 126 1974). The percentage of sand + silt fraction was determined by wet sifting of the samples 127 through $63 \mu \mathrm{m}$ sieve. Physical property measurements were made on whole, unsplit sections 128 of Core MD-2750 using a Geotek Multi-Sensor Core Logger equipped with gamma density, 129 P-wave velociy and magnetic susceptibility sensors (Boyce, 1976; Gerland and Villinger, $130 \quad$ 1995; Breitzke, 2000).

\section{3. RESULT AND DISCUSSION}

\section{3.1. Seismic and core stratigraphy}

134 We identified eight reflector surfaces including the seafloor and seven seismic units 135 deposited during the late glacial maximum (LGM) to present (Fig. 4). Late glacial lowstand 136 unconformity surface is represented in the seismic profiles by reflection surface K (Figs. 4, 5 137 and 6), which extends into the shelf break at about $-100 \mathrm{~m}$. Lowermost seismic unit (Unit 7) 138 was therefore deposited over the truncation surface K during the deglaciation period (Fig. 4).

139 Lowermost part of the Unit 7 correlates with shoreface deposits formed during formation of a 140 wave-cut terrace at ca. $-81 \mathrm{~m}$ on the eastern shelf of the paleo-strait's channel (Fig. 5). This 141 can be correlated with the $12 \mathrm{kyr}$ BP old $-85 \mathrm{~m}$ shoreline observed in different parts of the

142 SoM (Çağatay et al., 2003; Polonia et al., 2004). Reflection surface G truncates Unit 7 (Fig. 143 4), onto which Unit 6 was deposited. While the minumum depth of the reflector G is around -

$14480 \mathrm{~m}$, the sealevel must be above during truncation of the Unit 7, therefore, approximate age 145 of this reflector can be estimated as $11.2 \mathrm{kyr}$ BP according to global sealevel curves of 146 Fairbanks, (1989) and Sid all et al (2003). 
148 the main channel and dipping in opposite directions (Figs. 5 and 6). We interpret this unit as

149 a levee deposited in the main paleo-strait's channel. The lowermost $175 \mathrm{~cm}$ part of Core MD-

1502750 represents the upper part of the levee deposit (Unit 6), which comprises silty and sandy

151 beds with marine molluscan shells (Figs. 3b and 7). This unit is differentiated from the

152 overlaying other units by its relatively coarse-grained nature. Its sand + silt fraction in the

153 core amounts to $10-47 \%$ of the total sediment (Fig 8). The coarse-grained nature of the levee

154 sediments is also shown in the Gamma-density and P-wave velocity profiles, which show

155 normal grading in upper part of the unit (Fig. 9). Magnetic susceptibility values increase

156 towards to the top of the unit (and lower part of Unit 5) because of high clay input, probably

157 enhanced with a ferromagnetic componenet of diagenetic origin.

The levee unit is overlaid by Unit 5 over truncutaion surface E (Figs.4, 5 and 6), which corresponds to the onset of the early Holocene Sapropel (Çăgatay et al., 2000; Tolun et al.,

161 2002) as indicated by high Corg values (>1.5 wt\%) and its stratigraphic position in Core MD-

1622750 (Figs. 3b and 3c). This sapropelic layer was previously dated 10.6-6.4 kyr BP by

163 Çağatay et al. (2000). Its onset age is consistent with the ${ }^{14} \mathrm{C}$ ages of $10.95 \mathrm{kyr} \mathrm{BP}$ and 10.45

164 kyr BP obtained below and above truncation surface E, therefore, age of the reflector E can be 165 estimated as $10.6 \mathrm{kyr}$ BP (Fig. 3b). Eastern part of the study area, reflector E is associated by 166 a formation of wave-cut terrace at $-71 \mathrm{~m}$ (Fig. 6). Timing of this wave-cut terrace can be 167 estimated as $10.6 \mathrm{kyr}$ BP, when the Early Holocene sapropel deposition began in the SoM. On 168 the basis of these chronostratigraphic data, we can tentatively estimate the age of Unit 6 169 between 11.2 and $10.6 \mathrm{kyr}$ BP. 
Unit 5 is characterized by moderately continuous, subparallel internal reflections

172 forming a mud drape accumulated over the levee deposits in the main paleo-strait's channel

173 (Fig. 4). In Core MD-2750, Unit 5 comprises marine shelly homogeneous clay in the lower

174 part and grades into finely parallel and cross laminated silt (Figs. 3b and 7). Transition from

175 Unit 6 to 5 is represented by a decreasing grain size that is shown in the Gamma den sity

176 measurement (Fig. 9). Despite the decreased grain size in the lower part of Unit 5 the P-wave

177 velocity is high probably due to a low porosity caused by core compaction. The upper parallel

178 and cross laminated part of Unit 5 is represented by a relatively low Gamma density, but high

179 P-wave velocity values because of the increased silt content (Fig. 9). Unit 5 is followed

180 upward by Unit 4 over unconformable reflection surface D (Fig. 4). Timing of this reflector

181 surface can be assigned to $-63 \mathrm{~m}$ paleo-shoreline, while formation of a wave-cut terrace

182 truncated the sediment below reflector D on the eastern part of the main paleo-strait's channel

183 (Fig. 5). The erosion above Unit 5 is shown by a truncation of the laminations in Core MD1842750 (Fig. 7).

Age of the -63 m shoreline from the global sealevel curves (Fairbanks, 1989 and Sidall

187 et al., 2003) can be estimated as ca. 10-9.8 kyr BP. The same reflector (surface D) was dated

188 by Aksu et al. (2002) as $9.8 \mathrm{kyr}$ BP in the southern shelf of SoM, which is supported by the 189 global sealevel curves (Fairbanks, 1989 and Sidall et al., 2003) for this period. According to

190 chronostratigraphic relation of the underlying and overlying reflector surfaces of Unit 5, this

191 unit was deposited between 10.6-9.8 kyr BP. Unit 4 is characterized by mud drape in the main

192 paleo-strait's channel showing moderately continuous parallel internal reflectors (between

193 reflectors D and C in Figs. 5 and 6). It is associated by the formation of $-63 \mathrm{~m}$ paleo-shoreface

194 deposits between reflectors D and C on the eastern part of the main paleo-strait's channel

195 (Fig. 6). The shoreface deposits indicate progradational clinoforms characterized by 
acoustically strong internal reflectors. In Core MD-2750, Unit 4 comprises finely parallel and cross laminated clayey silt with marine shell (Figs. 3b and 7). Seismic Unit 4 together with Unit 3 correspond to the upper part of the early Holocene Sapropel layer as indicated by high organ ic carbon value (>1.5\%) (Fig. 3c).

Unit 3 overlies the progradational Unit 4 over reflection surface C (Fig. 4). It represents laterally continuous, regularly reflective package of weak internal reflectors (Figs. 5 and 6). In Core MD-2750, Unit 3 consists of homogenous silty clay with marine molluscs (Fig. 7). It is bounded at the top by reflection surface B, which corresponds to termination of the early Holocene Sapropel (6.4 kyr BP, Çağatay et al., 2000; Figs. 3b and 3c). This is in agreement with a ${ }^{14} \mathrm{C}$ age of $6460 \mathrm{yr}$ BP obtained from the upper part of the Unit 3 (Figs. 3b and 3c). We can bracket the age of the package including Units 4 and 3 between 9.8 and 6.4 kyr BP.

(1)

Unit 2 conformably overlay Unit 3 (Fig. 4), and consists of oblique clinoforms with acoustically strong reflectors (Figs. 6 and 10) that represent the presence of delta foresets composed probably of relatively coarse sediments. According to architectural features of the foresets, the delta comprises lower progradational and upper aggradational parts (subunits $2 \mathrm{a}$ and 2b) (Fig. 6). Offshore equivalent of Unit 2 is represented in Core MD-2750 by shelly clayey silt in the lower part (subunit 2a) and silty clay with marine mollusc shells in the upper part (subunit 2b; Figs. 3b and 9). Considering the Corg profile, the upper subunit (Unit 2a) correlates with the late Holocene Sapropelic layer between 215-295 cm in the core (Fig. 3b and 3c), hav ing a depositional age of 4750-3200 yr BP (Çağatay et al., 1999). This shows that the onset of the late Holocene Sapropelic layer corresponds to initiation of the aggradational deltaic deposition ca. $4.7 \mathrm{kyr} \mathrm{BP}$, and its termination can be correlated with the end of the 
deltaic deposition ca. 3.2 kyr BP (Figs. 3b and 3c). Delta topset beds are represented in Core

222 TSU03-13 by pebbly sands with marine mollusc shells (Fig. 3a). An ${ }^{14} \mathrm{C}$ age of $4.4 \mathrm{kyr}$ BP 223 was obtained in Core TSU03-13 near the upper part of the topset beds (Fig. 3a) that are 224 truncated by an overlying reflection surface A at $-35 \mathrm{~m}$ (Figs. 6 and 10). The truncation 225 implies subaqueous erosion of the delta platform after termination of the delta deposition. 226 Considering the $4.4 \mathrm{kyr}$ BP age from the delta topset and correlation with its upper part with 227 the late Holocene Sapropelic layer, the age of the deltaic unit (Unit 2) can be delimited 228 between 6.4 and $3.2 \mathrm{kyr}$ BP. The delta deposits of Unit 2 is overlain by Unit 1 above 229 truncation surface A (Figs. 4 and 5).

The boundary between Units 2 and 1 is bioturbated in Core MD-2750, a typical 232 feature of sapropelic sediments (Figs. 7 and 10). Transition from Unit 2 to Unit 1 is indicated by an abrupt increase in the magnetic susceptibility (Fig. 9). It seems that the Unit 2/Unit 1 boundary represents a redox front at the top of the sapropelic Unit 2, below which the ferromagnetic component of the sediments is reduced and sulfidized.

Unit 1 consists of a package of moderately continuous and regular reflectors, representing onlapping sediments over truncation surface A. In Core TSU03-13, Unit 1 consists of shelly and sandy silt intercalated with silty sand containing marine mollusc shells, grades in to clayey silt in the upper part (Fig. 3a). In the paleo-strait's channel, it is represented

241 by clay with marine shells infilling the topographic irregularities (Figs. 3b, 5 and 6).

\subsection{Kurbağalıdere River: its drainage area and water and sediment discharges}

244 Present day Kurbağalıdere River has several small tributaries, draining a total area of $24546 \mathrm{~km}^{2}$ with a steep topography (Fig. 11). The drainage area consists mainly of schist, 
greywacke, limestone and quartize of Palaeozoic age and Neogene sand and gravel. The

247 highest elevation of the catchment area is around $180 \mathrm{~m}$. Present day mean discharge rate is 248 about 80 m³/yr (DSİ İstanbul, unpublished data). Suspended sediment load of Kurbağalıdere

249 River has not been measured. We estimated this load to be around 60, 000 ton/yr based on the

250 data of other rivers in the southern Marmara region (Table 2; EİE, 1993). We accept this 251 value to be also representative of the pre-antropocene period. In the Marmara region, it is 252 estimated that total sediment flux of rivers to be $35 \%$ more than the measured suspension 253 sediment flux because of retention behind reservoirs and additional bedload (EIE, 2000; 254 Kazanc1 et al, 2004). The bedload constitutes about $10 \%$ of the total sediment influx 255 (Milliman and Mead, 1983). The total sediment retained behind dams and the bedload is 256 assumed to balance the opposite effects of deforestation and cultivation, based on the 257 conclusion of Svitski et al (2005) that the opposite effect of different human activities on the 258 sediment yield on a global scale is almost in balance.

\subsection{Evolution of the Delta}

261 Source and depositional period of the delta can be confidently deduced from the 262 correlation of the seismic stratigraphic units with the chronostratigraphic units in the cores.

263 The seismic units identified by us and Hiscott et al. (2002) can be correlated, while two sets

264 of profiles used by Hiscott et al (2002) and this study cross each other at the intersections 265 (Fig. 2). Seismic interpretations of both studies can be compared and correlated with high 266 confidence (Figs. 2 and 12). Seismic stratigraphic Units 2 and 3 of this study corresponds to 267 the deltaic unit (Unit 2 between $\beta 1$ and $\beta 2$ reflectors) of Hiscott et al. (2002). Unit 3 defined 268 by us is clearly not a part of the delta, because the delta foresets downlap onto reflector B 269 lying above Unit 3 (Figs. 6 and 10). This important disparity in the seismic interpretation, 270 produces significant differences in the delta isopach maps of the two studies (Fig. 13). Our 
271 isopach map shows the presence of a delta lobe extending southwestwards, with the thickest 272 part of the delta (20 and $22 \mathrm{~m}$ thickness contours) located close to the mouth of the 273 Kurbağalıdere River (Fig. 13). The delta forsets dip at an average of $7^{\circ}$ not only towards SW,

274 but also towards W and SE, radially diverging from the Kurbağalıdere River's mouth and 275 having true dips of up to $12^{\circ}$ (Fig. 13). This delta geometry strongly suggests that the delta is 276 sourced from the Kubagalıdere River. The delta also extends northwards towards the SoI.

277 This northward extension is because of the strong outflow of the Mediterraean water to the 278 Black Sea through the SoI, which started about 8.4 kyr BP (Major et al., 2002, Ryan et al., 279 2003). Such an outflow could easily redistribute the deltaic sediments further north of the 280 Kurbağalidere River mouth. There is no other river of reasonable size in the north of the 281 Kurbağalıdere River to cause a northward extension of the delta from the river's mouth (Fig. 282 8). A similar transport mechanism by the undercurrent has been suggested for the formation 283 of the $-35 \mathrm{~m}$ southern sill of the Bosphorus by Algan et al. (2001). There, the sediment input 284 by the Alibeyköy and Kağıthane into the Golden Horn estuary was eventually transported 285 nortwards into the strait's channel and piled up between Dolmabahçe and Üsküdar to form the 286 southern sill (see Fig. 1b).

In addition to the above facts, there are three other important lines of evidence against 289 the persistent Black Sea outflow origin of the delta as proposed by Hiscott et al. (2002) and 290 Aksu et al. (2002). First, the source of sediments of such an outflow delta is unexplained. The 291 sediment derived from land on either side of the SoI's channel would be trapped in the $-80 \mathrm{~m}$ 292 deep, sediment-starved depressions along the SoI's channel, such as the Beykoz and Bebek 293 basins (Gökaşan et al., 1997; Algan et al., 2001). In contrast to Black Sea outflow hypothesis 294 of Hiscott et al (2002), formation of levee deposits in the paleo-SoI channel indicates that a 295 Black Sea outflow took place during 11.2-10.6 kyr BP according to our seismic and core data. 
Second, according to the contour maps of both overlying and underlying reflectors (A

and B in Fig. 4) of the deltaic deposits, there was southwards flows of the paleo-strait's channel before the onset and after termination of the delta (Figs. 14 and 15). Instead a delta proposed to have been formed by a Black Sea outflow during 10-9 kyr BP would be expected near the edge of the shelf at a water depth of $65 \mathrm{~m}$. However, the contour map of the reflector considerably smooth (Fig. 14). This indicates that Kurbağalıdere River was in its backfilling phase because high rate of sealevel rise that gave rise to further incursion of the sea into the river valley untill sealevel rise slowed down at ca. $6.4 \mathrm{kyr}$ BP. In contrast, the contour map of the reflector A shows that there was still chanellizing from the Kurbağalıdere River although deltaic deposition was terminated (Fig. 15). After the delta deposition was ceased, the amount of sealevel rise might have been relatively faster for delta deposition on the shelf area even there was still sediment influx from the Kurbağalıdere River. After termination of the delta deposition, the channel transect of the Kurbağalıdere River is well adjusted with the spreading

311 of the deltaic deposits, clearly showing source of the delta (Figs. 13 and 15). Third, the base

312 of the subaqueous delta is above $-50 \mathrm{~m}$ which at a much higher elevation of the sealevel ca.

$31310 \mathrm{kyr}$ BP, which was at ca. -65 $\mathrm{m}$ according to the global sea level curves (Fairbanks, 1989;

314 Siddal et al., 2003).

Based on the seismic stratigraphic and chronostratigraphic core analysis, the period of

317 the delta formation (6.4-3.2 kyr BP) determined by this study is in disagreement with $10-9 \mathrm{kyr}$

318 BP age given by Hiscott et al. (2002) and 11-10 kyr BP by Gökaşan et al. (2005). Hiscott at 319 al. (2002) determined the age of delta from a $1.25 \mathrm{~m}$ long core (MAR98-09 in Fig 13) that is 320 supposed to include the whole delta unit between reflectors $\beta 1$ and $\beta 2$. The delta unit as 
321 defined by Hiscott et al. (2002) includes older sediments (Unit 3 in this study) which is

322 clearly not a part of the delta. Morever, Gökaşan et al. (2005) used shallow seismic lines on

323 the northern shelf and correlated the seismic units with a drill-hole section in the

324 Kurbağalidere River valley to discuss the source and age of the delta. They obtained an 325 electron spin resonance (ESR) age of $11,000 \pm 1100 \mathrm{yr}$ BP for an unconformity at $-18 \mathrm{~m}$, which 326 they consider to represent the onset of delta deposition during the Younger Dryas. This age 327 has a large error margin and is not compatible with the global sealevel of -75 to $65 \mathrm{~m}$ 328 (Fairbanks, 1989 and Sidall et al., 2003) for that time period.

We propose the following sequence of events leading to the delta formation.

331 According to global sealevel curves (e.g. Fairbanks, 1989 and Sidall et al. 2003), the rate of 332 sealevel rise decreased after ca. 6.5 kyr BP. This decrease combined with an increase in 333 sediment supply during mid-Holocene climatic optimum resulted in the deltaic progradational 334 sedimentation on the shelf of southern enterance of SoM to SoI. This conclusion is in 335 agreement with the fact that the mid-Holocene is a well known period for widespread delta 336 development (Stanley and Hait, 2000). The change from the progradational stage to the 337 aggradational stage of delta development at $4.7 \mathrm{kyr}$ BP is marked by a relatively rapid rise of 338 sealevel as indicated by climbing delta foreset-topset transition (Fig. 6). The onset of 339 aggradational period also coincides with establishment of the present dual-flow regime 340 (Çağatay et al., 2000; Algan et al., 2001) with the Mediterranean under-current in the SoI, 341 forming a northward sediment drift. The delta deposition was terminated when increased base 342 level due to further global sealevel rise combined with a probable decrease in sediment input 343 by the Kurbağalıdere River at ca $3.2 \mathrm{kyr}$ BP. This date is supported by the correlation with the 344 age of the late Holocene Sapropel layer and by a ${ }^{14} \mathrm{C}$ age of $4.4 \mathrm{kyr}$ BP in Core TSU03-13 345 below the eroded uppermost topsett bed (Fig. 3a). The Kurbagalidere River, with a present 
day annual water and sediment discharges of $80 \mathrm{~m}^{3}$ and 60.000 tons (EİE, 1993) draining a

$347180 \mathrm{~m}$ high ground southeast of the SoI, is large enough to form such a delta having about $348290 \times 10^{6}$ tons of sediment.

\section{CONCLUSIONS}

Seismic-stratigraphic and chronostratigraphic analyses near SoM entrance of the SoI provide important information on sealevel changes since the LGM. The sedimentary sequence in this area is deposited over the LGM a erosional surface and includes seven seismic units that can be confidently correlated with ${ }^{14} \mathrm{C}$-dated chronostratigraphic units in the cores. In the paleo-SoI channel, there is levee representing Unit 6 that implies a Black Sea outflow during 11.2-10.6 kyr BP. The reflection surfaces at base of Unit 5 and 4 are wave-cut platforms at 71 and $-61 \mathrm{~m}$, corresponding to sealevel stil stand periods around 10.6 and $9.8 \mathrm{kyr} \mathrm{BP}$.

The seismic unit 2 is interpreted as a deltaic deposits. The isopach map of this delta unit, together with the delta foreset dips, shows that the source of the deltaic sediments is

362 Kurbagalidere River draining a $46 \mathrm{~km}^{2}$ topographically high area southeast of the SoI. The 363 progradational delta deposition started ca $6.4 \mathrm{kyr}$ BP when rate of sealevel rise slowed down 364 and sediment input increased during the mid-Holocene climatic optimum until $4.7 \mathrm{kyr}$ BP.

365 The progradational stage of delta deposition was followed by an aggradational stage during 4.7-3.2 kyr BP, which is characterized by a climing topset-foreset transition. During this 367 second stage of delta development the rate of sealevel rise and sediment input were relatively 368 high. The onset of the aggradational delta stage corresponds in time to the establishment of 369 the present day dual-flow regime in the SoI and deposition of a sapropelic sediment layer on 370 the shelf areas of the SoM. Our findings contradict the Hiscott et al's (2002) hypothesis that 
371

372

373

374

375

376

377

378

379

380

381

382

383

384

385

386

387

388

389

390

391

392

393

394

this delta was sourced from the Black Sea and that it indicates a persistant Black Sea outflow since $10 \mathrm{kyr} \mathrm{BP}$.

\section{Referances}

Aksu, A.E., Hiscott, R.N., Kaminski, M.A., Mudie, P.J., Gillespie, H., Abrojano, T., Yaşar, D., 2002. Last glacial-Holocene paleoceanography of the Black Sea and Marmara Sea: stable isotopic, foraminiferal and coccolith evidence. Mar. Geol. 190, 119-149.

Algan, O., Çağatay, M.N., Tchepalyga, A., Ongan, D., Eastoe, C., Gökaşan, E., 2001.

Stratigraphy of the sediment infill in Bosphorus Strait: water exchange between the Black and Mediterranean Seas during the last glacial-Holocene. Geo-Mar. Lett. 20, 209-218.

Boyce, R.E., 1976. Definitions and laboratory techniques of compressional sound velocity parameters nd wet-water content, wet-bulk density, and porosity parameters by gravimetric and gamma-ray attenuation techniques. In Schlan ger, S.O., Jackson, E.D., et al., Init. Repts. DSDP, 33: Washington (U:S. Govt. Printing Office), 931-958.

Breitzke, M., 2000. Physical properties of Marine Sediments. In Schulz, H.D. and Zabel, M. (Eds.), Marine Geochemistry, Springer-Verlag Berlin Heidelberg New York, p 29-72.

Çağatay, M.N., Algan, O., Sakınç, M., Eastoe, C., Egesel, L., Balkıs, N., Ongan, D., Caner, H., 1999. A late Holocene sapropelic sediment unit from the southern Marmara shelf and its palaeoceanographic sign ificance. Quater. Geol. Rev. 18, 531-540.

Çağatay, M.N., Görür, N., Algan, A., Eastoe, C.J., Tchapalyga, A., Ongan, D., Kuhn, T., Kuşcu, İ., 2000. Late Glacial-Holocene palaeoceanography of the Sea of Marmara: timing of connections with the Mediterranean and the Black Sea. Mar. Geol. 167, 191-206. 
Çağatay, M.N., Görür, N., Polonia, A., Demirbağ, E., Sakınç, M., Cormier, M.-H., Capotondi,

396 L., McHugh, C., Emre, Ö., Eriş, K., 2003. Sealevel changes and depositional env ironments

397 in the İzmit Gulf, eastern Marmara Sea, during the late glacial-Holocene period. Mar.

$398 \quad$ Geol. 202, 159-173.

399 De Rijk, S., Rohling, E.J., Hayes, A., 1999. Onset of climatic deterioration in the eastern

$400 \quad$ Mediterranean around 7 ky BP; micropaleon tological data from Mediterranean sapropel.

401 EIEE., 1993. Sediment data and sediment transport amount for surface water in Turkey.

402 Türkiye Elektirik İşleri Etüd Dairesi Genel Müdürlüğü, Ankara, EIE Publ. No.68.

403 EİE., 2000. Türkiye akarsularında suspanse sediment gözlemleri ve sediment taşınım

404 miktarları (Suspended sediment data and sediment transport amount for surface waters in

405 Turkey). EIEI Genel Müdür. Yayın., 17-20 (Ankara).

406 Gaudette, H., Flight, W., Tones, L., and Folger, D., 1974. An inexpensive titration method for

407 the determination of organic carbon in recent sediments. J. Sediment. Petrol. 44, 249-253.

408 Gerland, S., and Villinger, H., 1995. Nondestructive density determination on marine

409 sediment cores from gamma-ray attenuation measurements. Geo-Mar. Lett. 15: 111-118.

410 Gökaşan, E., Demirbağ, E., Oktay, F, Y., Ecevitoğlu, B., Şimşek, M., Yüce, H. 1997. On the

411 origin of the Bosphorus. Mar. Geol. 140, 183-199.

412 Gökaşan, E., Algan, O., Tur, H., Meriç, E., Türker, A., Şimşek, M., 2005. Delta formation at

413 the southern enterance of Istanbul Strait (Marmara sea, Turkey): a new interpretation based

414 on high-resolu tion seismic stratigraphy. Geo-Mar. Lett. 25, 370-377.

415 Fairbanks, R.G., 1989. A 17,000-year Glacio-Eustatic sea level record: influence of glacial

416 melting rates on the Younger Dryas event and deep-ocean circulation. Nature 342, 637-

417642. 
Hiscott, R. N., Aksu, A. E., Yasar, D., Kaminski, M. A., Mudie, P. J., Kostylev, V. E., MacDonald, J. C. Isler, F.I., Lord , A. R., 2002. Deltas south of the Bosphorus Strait record persis tent Black Sea outflow to the Marmara Sea since 10 ka, Mar. Geol. 190, 95-118.

Kazanc1, N., Leroy, S., Ileri, Ö., Emre, Ö., Kibar, M., Öncel, S., 2004. Late Holocene erosion NW Anatolia from sediments of Lake Manyas, Lake Ulubat and the southern shelf of the Marmara Sea, Turkey. Catena 57, 277-308.

Kurt, H., 1994. Interpretation of high resolution seismic data offshore YedikuleBüyükçekmece (İstanbul) (in Turkish). İTÜ MSc thesis, 80 p.

Major, C., Ryan, W. Lericolais, G., Hajdas, I., 2002. Constraints on Black Sea outflow to the Sea of Marmara during the last glacial-interglacial transition, Mar. Geol. 190, 19-34.

Major, C.O., Vidal, L., Cagatay, N., Goldstein, S.L., Ryan, W.B.F., Ménot-Combes, G., Bard, E., Labeyrie, L., 2004. Comparison of isotopic records from the Marmara and Black Seas: Indications of marine connection, outflow and exchange. EGU 1st General Assembly, 2530 April 2004, Nice, France.

Milliman, J.D., and Meade, R.H., 1983. World-wide delivery of river sediment to the oceans, J. Geology 91 (1), 1-21.

Oktay, F.Y., Gökaşan, E., Sakınç, M., Yaltırak, C., İmren, C., Demirbă̆, E., 2002. The effects of the North Anatolian Fault Zone on the latest connection between Black Sea and Sea of Marmara, Mar. Geol. 190, 367-382.

Polonia, A., Gasperini, L., Amorosi, A., Bonatti, E., Bortoluzzi, G., Çă̆atay, N., Capotondi, L., Cormier, M.-H., Görür, N., McHugh, C., Seeber, L. 2004. Holocene slip rate of the North Anatolian Fault beneath the Sea of Marmara. Earth and Planet. Sci. Lett. 227, 411426. 
Ryan, W. B. F., Pitman III, W.C., Major, C.O., Shimkus, K., Moskalenko, V., Jones, J. A.,

442 Dimitrov, P., Görür, N., Sakınç, M. and Yüce, H., 1997. An abrupt drowning of Black Sea

443 shelf. Mar. Geol. 138, 119-126.

444 Ryan, W.B.F., C. Major., Lericolais, G. and S.L., Goldstein., 2003. Catastrophic Flooding Of

445 the Black Sea. Annu. Rev.Earth Planet.Sci. 31, 525-554.

446 Siddall, M., Rohling, E.J., Almogl-Labin, A., Hemleben, Ch., Melschner, D., Schmelzer, I.,

447 Smeed, D.A. 2003. Sea-level fluctiations during the last glacial cycle. Nature 243, 853-

$448 \quad 858$.

449 Stanley, D.J. and Hait, A.K., 2000. Deltas, radiocarbon dating, and measurements of sediment $450 \quad$ storage and subsidence. Geology 24, 295-298.

451 Syvitski, J.P.M., Vörösmarty, C.J., Kettner, A:J:, Green, P., 2005. Impact of human on the 452 flux of terrestrial sediment to the global coastal ocean. Science 308, 376-380.

453 Tolun, T., Çağatay, M.N., Carrigan, W.J., 2002. Organic geochemistry and origin of 454 Holocene sapropelic layer and associated sediments in Marmara Sea. Mar. Geol. 190, 4745560.

456

457

458

459

460

461

462

463

464 


\section{Figure Captions}

472 Fig. 1. Bathymetric map of the Sea of Marmara (SoM) (a). Inset maps: (b) southern enterance 473 of the Strait of Istanbul (SoI) and Golden Horn, (c) bathymetry of Bakırköy shelf, (d) SoI's 474 entrance to the SoM showing studied seismic profiles. Contours are in meters.

475

Fig. 2. Present bathymetric map of Sea of Marmara entrance of the İstanbul Strait created by using seismic profiles and additional SHOD data. It shows seismic profiles and gravity cores studied in this study. Broken lines are the sesimic profiles were studied by Hiscott et al. (2002).

480 Fig. 3. Lithological logs of the gravity cores TSU03-13 (a), MD-2750 (b), and organic carbon 481 (Corg) distribution in Core MD-2750 (c). Letters A to E denote the seismic reflecters 482 bounding seismic units 1-6, which are correlated with the lithological units.

484 Fig. 4. Generalized seismic stratigraphic units in the seismic profiles defined by this study and 485 their depositional facies observed in paleo-channel of SoI and on shelf.

487 Fig. 5. High-resolution seismic profile K4 showing wave-cut terraces at $-81 \mathrm{~m}$ and $-63 \mathrm{~m}$ and 488 a levee deposit between $\mathrm{G}$ and E reflectors. It also shows location of Core MD-2750

489 intersecting the uppermost part of the levee deposits. Prograded shoreface sediments are 
491 surfaces that truncate the und erlying beds.

492

493 Fig. 6. High-resolution seis mic profile K2 showing formation of wave-cut terrace at $-71 \mathrm{~m}$ and shoreface sediments of -63 m paleoshoreline. Deltaic deposit comprises lower progradational and upper aggradational foreset beds between B and A reflector surfaces. Seismic reflectors of $\mathrm{B}, \mathrm{D}, \mathrm{E}, \mathrm{G}$ and $\mathrm{K}$ are erosional surfaces that truncate the underlying 497 beds.

Fig. 7. Photos of Core MD-2750 showing differentiated litho stratigraphic units and their

500 litologic and stratigraphic features. Letters A to E denote the seismic reflecters bounding 501 seismic units 1-6, which are correlated with the lithological units. S1-S9 are section numbers 502 of the splitted core and S1 is the uppermost section of the core.

503

504 Fig.8. The percentage of sand + silt fraction in Core MD-2750 determined by wet sifting of 505 the samples through $63 \mu \mathrm{m}$ sieve.

507 Fig. 9. Lithologic log of Core MD-2750 (a) and physical property measurements made on unsplit sections of the core using a Geotek Multi-Sensor Core Logger (b).

510 Fig. 10. High-resolution seismic profile K3 showing delta deposits bound by reflectors A and

511 B, and location of Core Tsu03-13 intersecting the delta topset. Notice the delta forsets dipping 512 in opposite directions and topsets truncated at $-35 \mathrm{~m}$.

513

514 Fig. 11. Topographic map of the catchment area of the Kurbağalıdere River. 
516 Fig. 12. Correlation of the chronostratigraphy of the seimic stratigraphic units defined by this 517 study and Hiscott et al. (2002). The delta un it corresponds to Unit 2 in this study and Units 2

518 and 3 in Hiscott et al.'s study.

519

520

Fig. 13. Comparison of isopach maps obtained by this study (continuous lines) and Hiscott et al. (2002) (dashed lines). Circles in a different symbol show locations of the cores used by

522 this study (Tsu03-13 and MD2750) and by Hiscott et al. (2002) (MAR98-09). Note the arrows 523 indicating the true dip direction of the delta foresets. The isopach contours are in meters.

525 Fig. 14. Con tour map of the reflector B showing paleo-bathymetry of the southern enterance 526 of the SoI prior to delta deposition. The contours are in meters.

527

528 Fig. 15. Con tour map of the reflector A showing paleo-bathymetry of the southern enterance 529 of the SoI after delta deposition ceased. The contours are in meters. 
Click here to download high resolution image

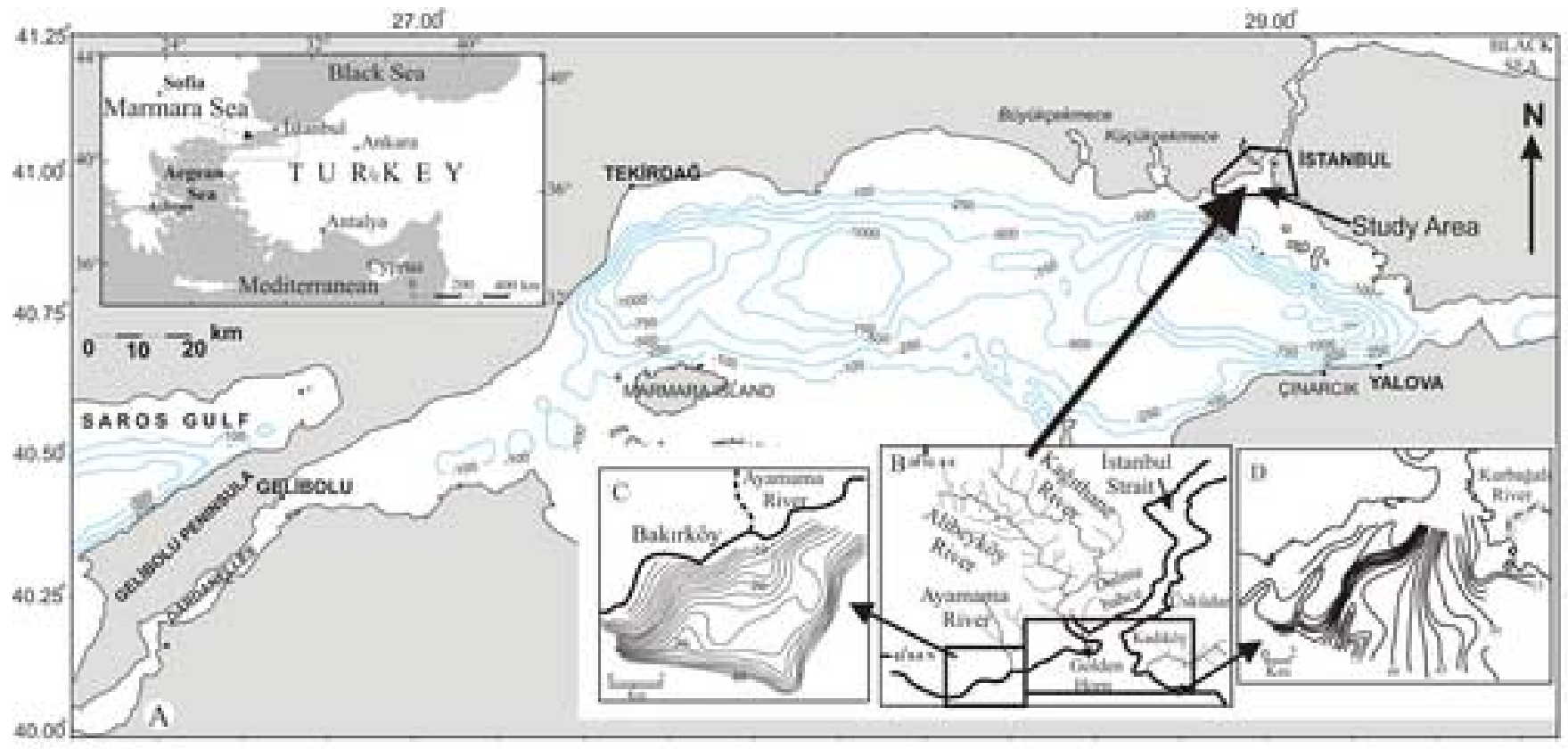

Figure 1 
Figure 2

Click here to download high resolution image

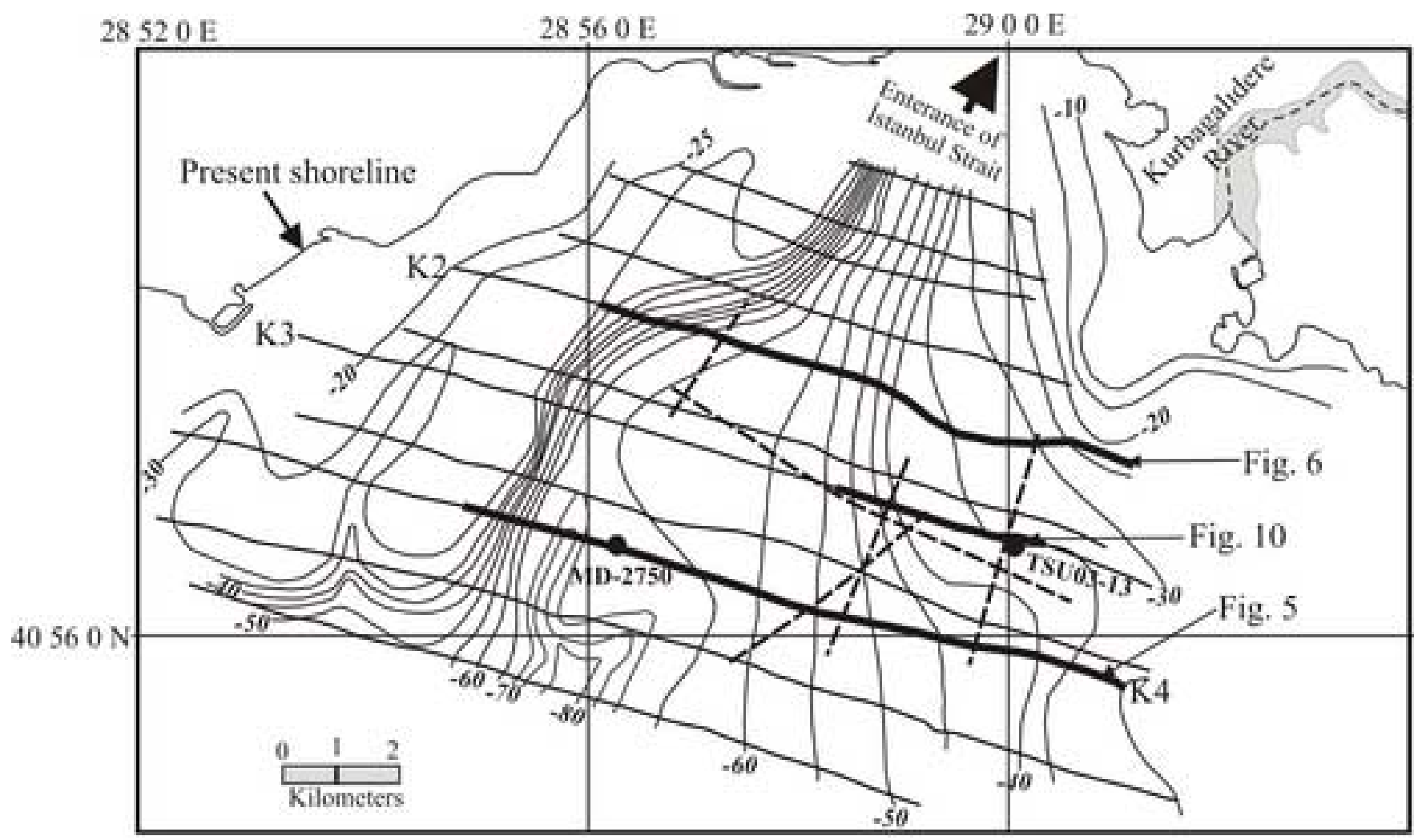

Figure 2 


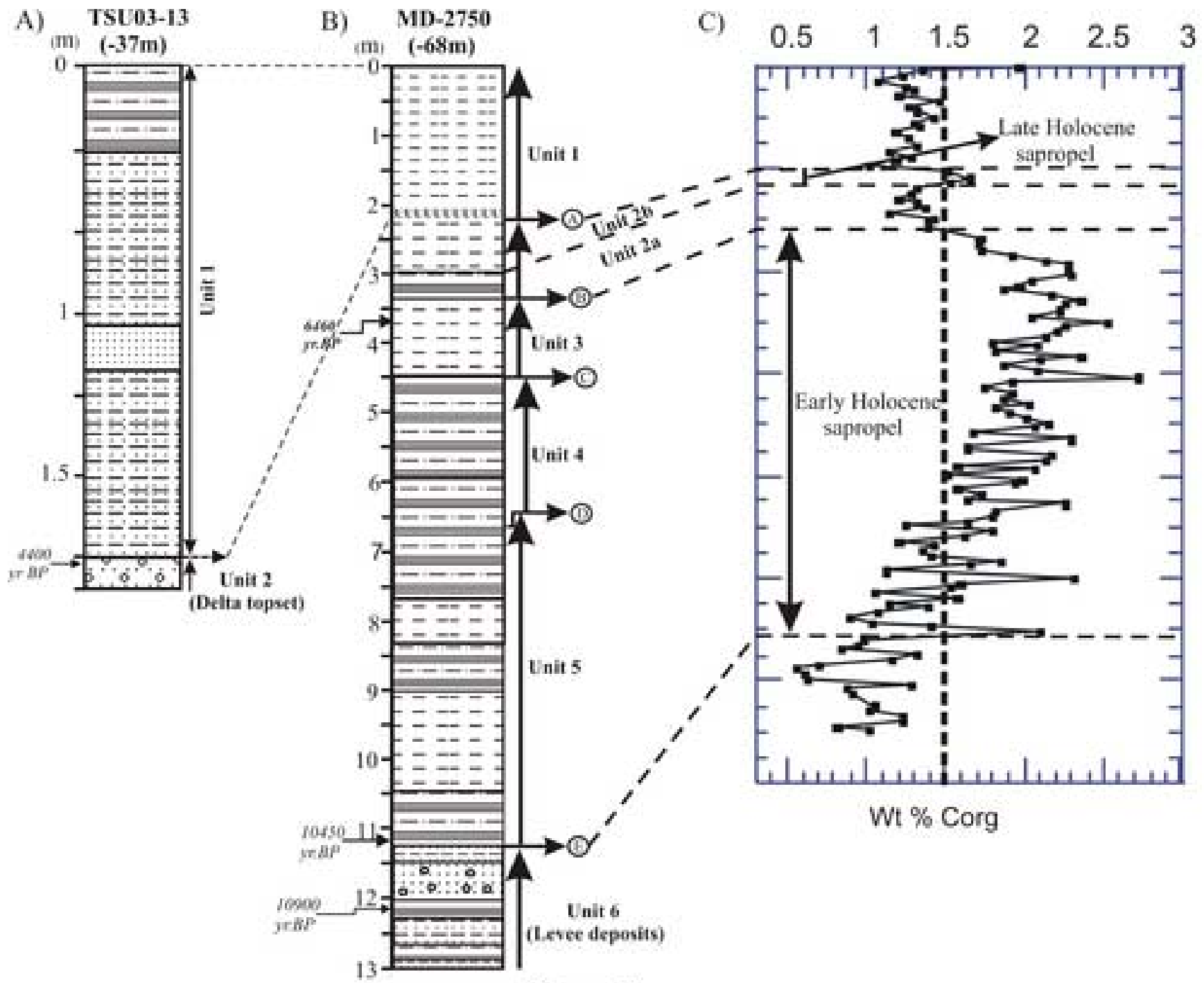

Figure 3 


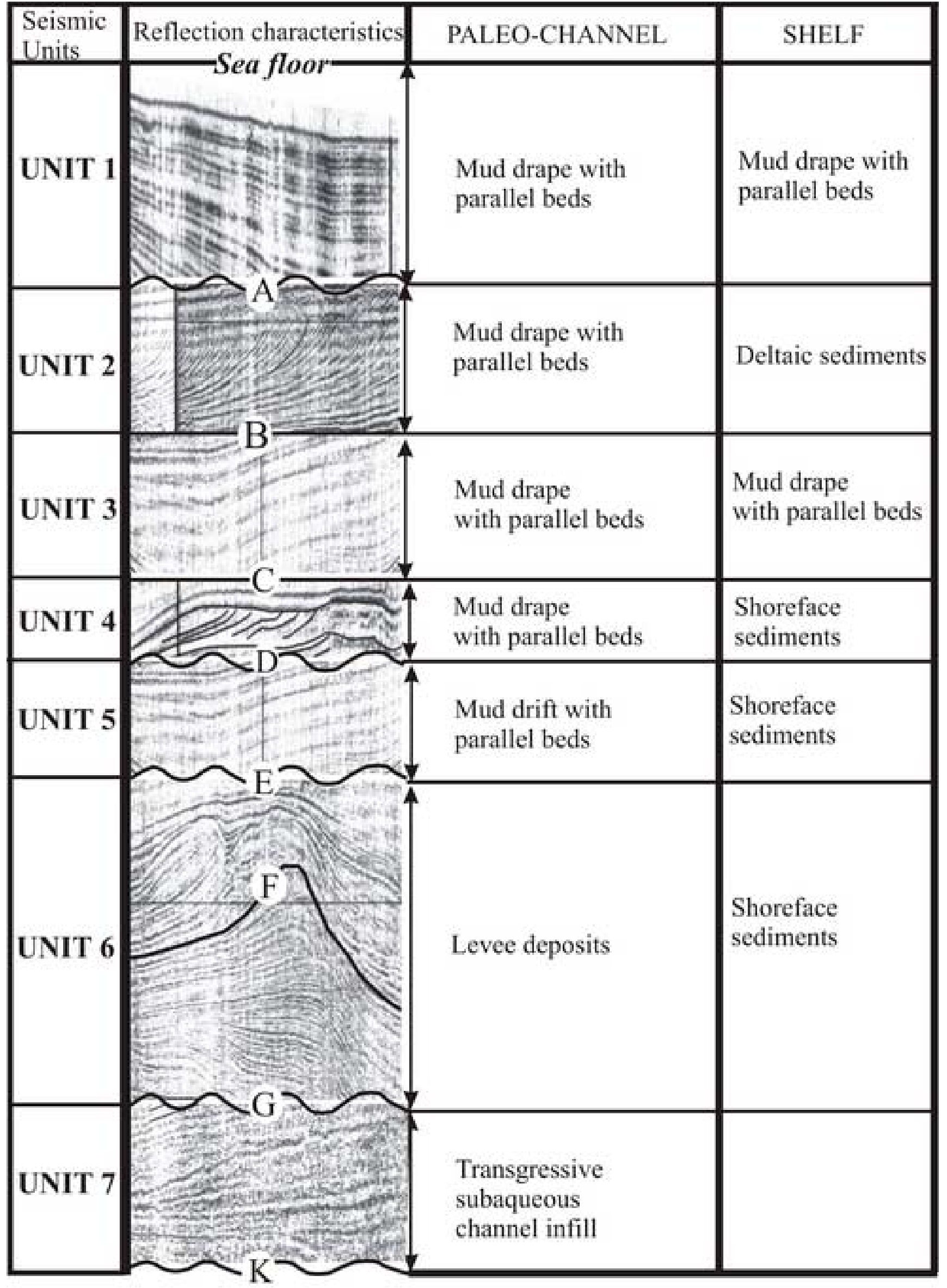

Figure 4 
Figure 5
Click here to download high resolution image

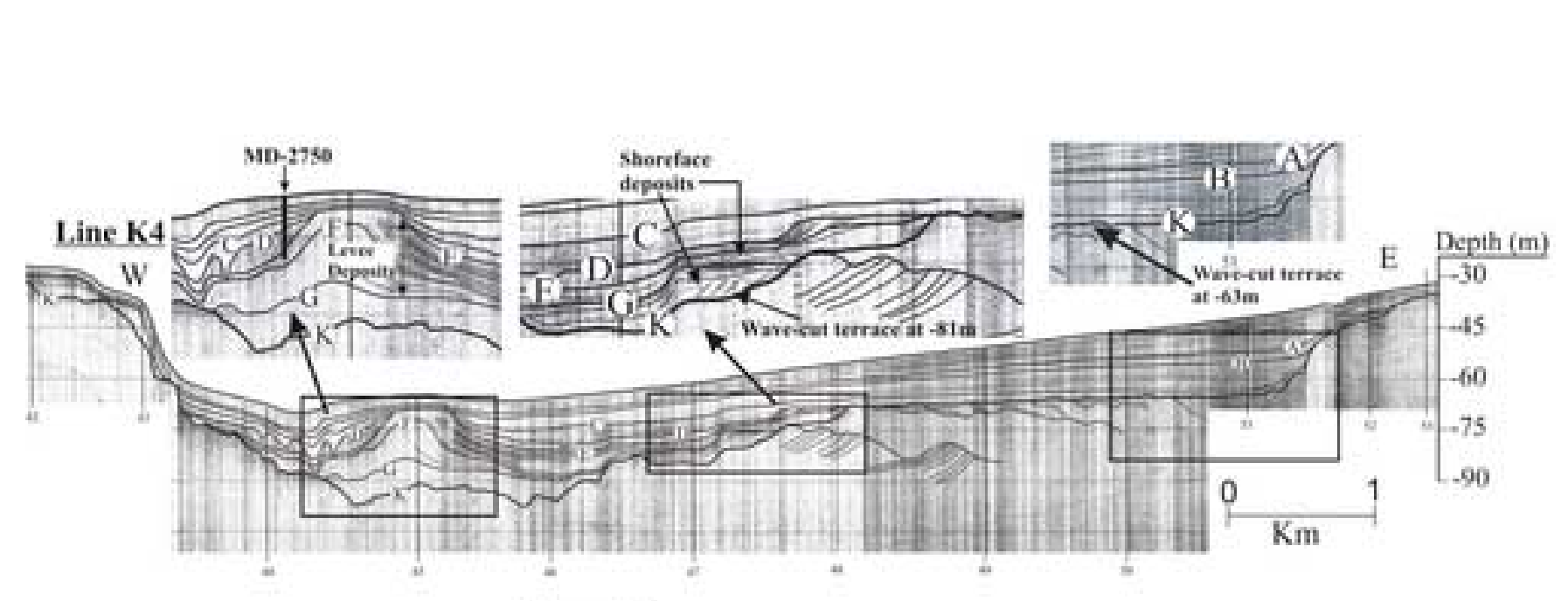

Line K4

Figure 5

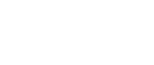
s. (2)

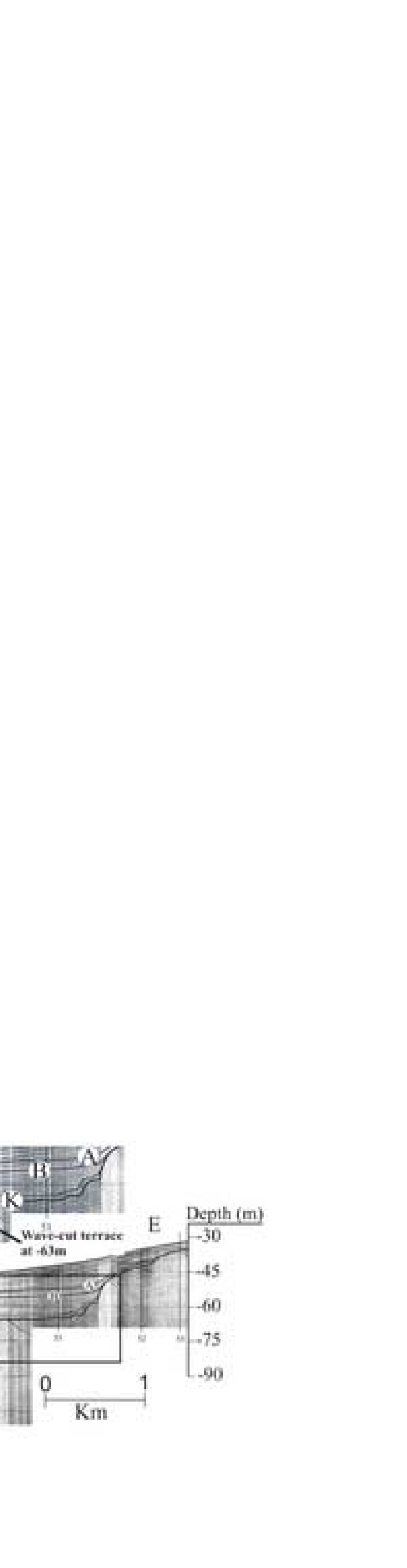


Click here to download high resolution image

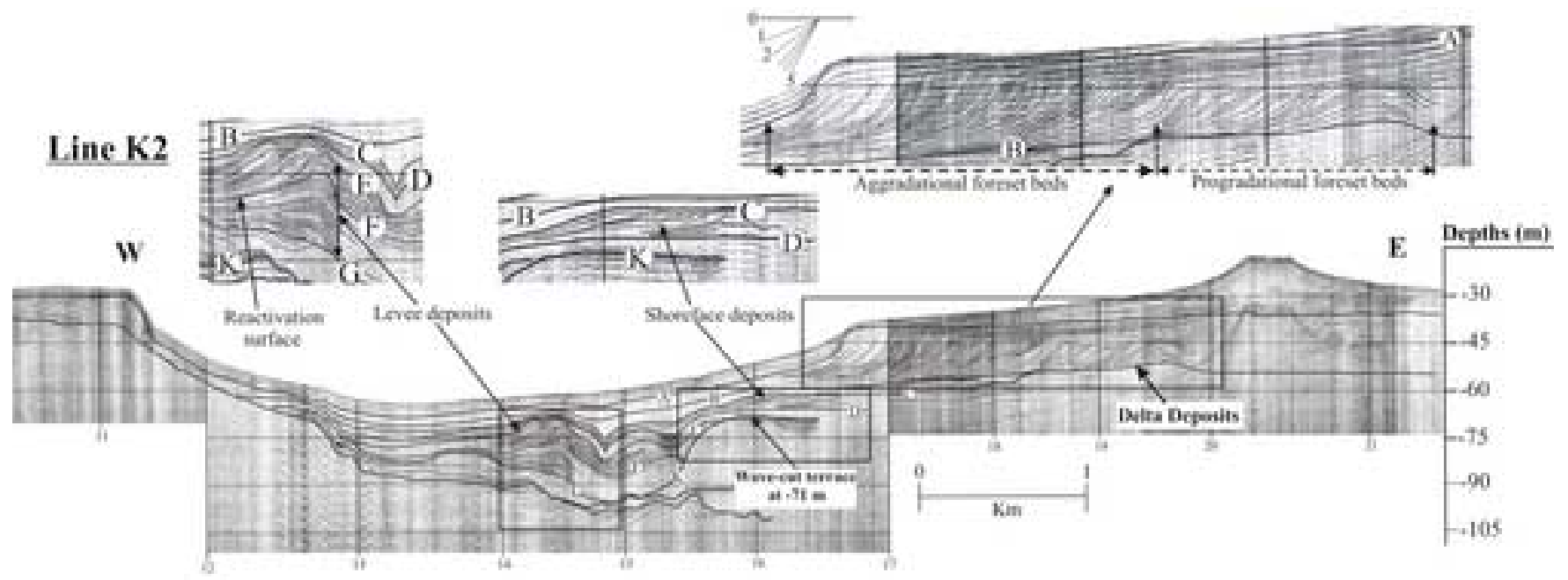

Figure 6 
Figure 7
Click here to download high resolution image

Core MD-2750

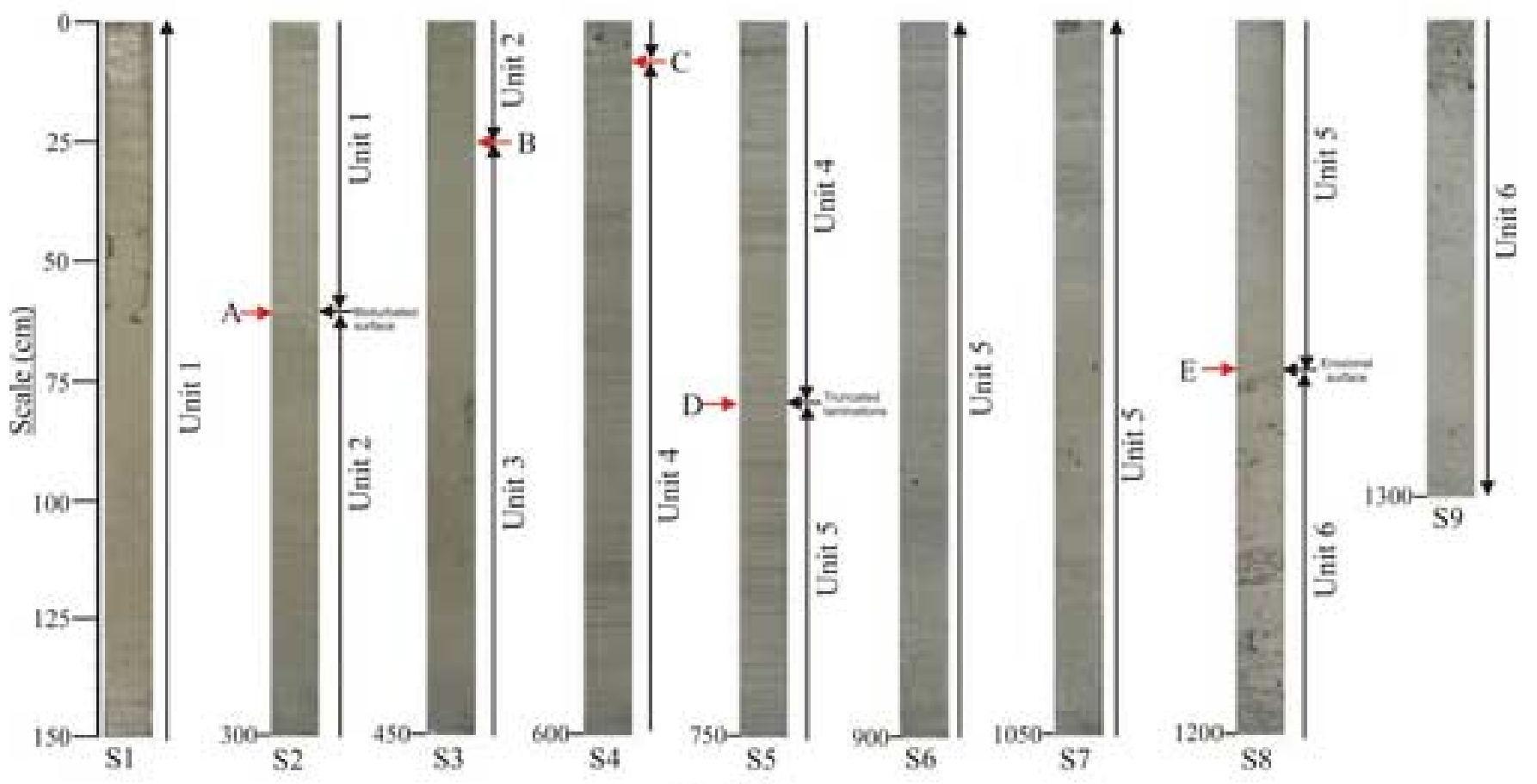

Figure 7 
Click here to download high resolution image

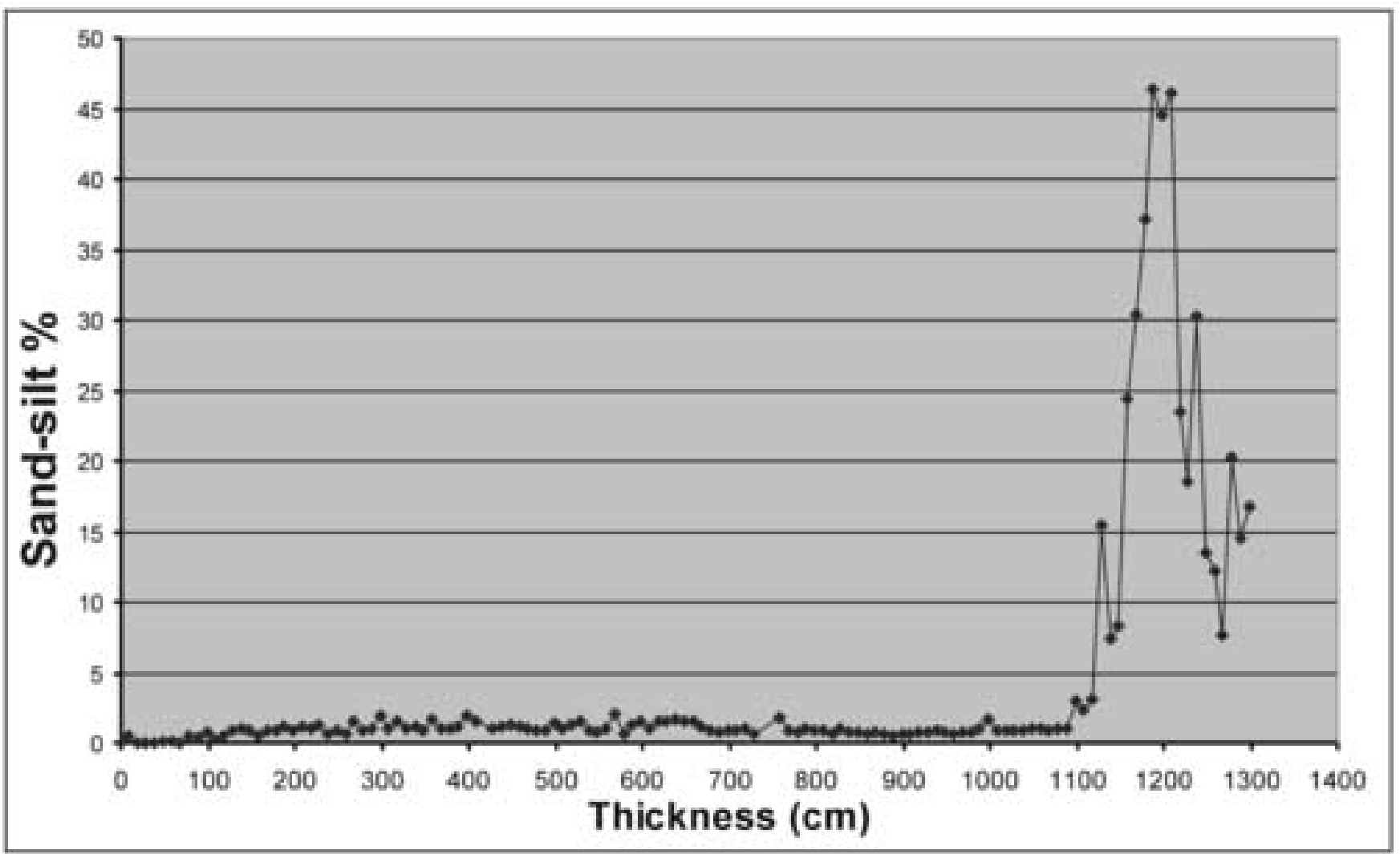


Figure 9

Click here to download high resolution image

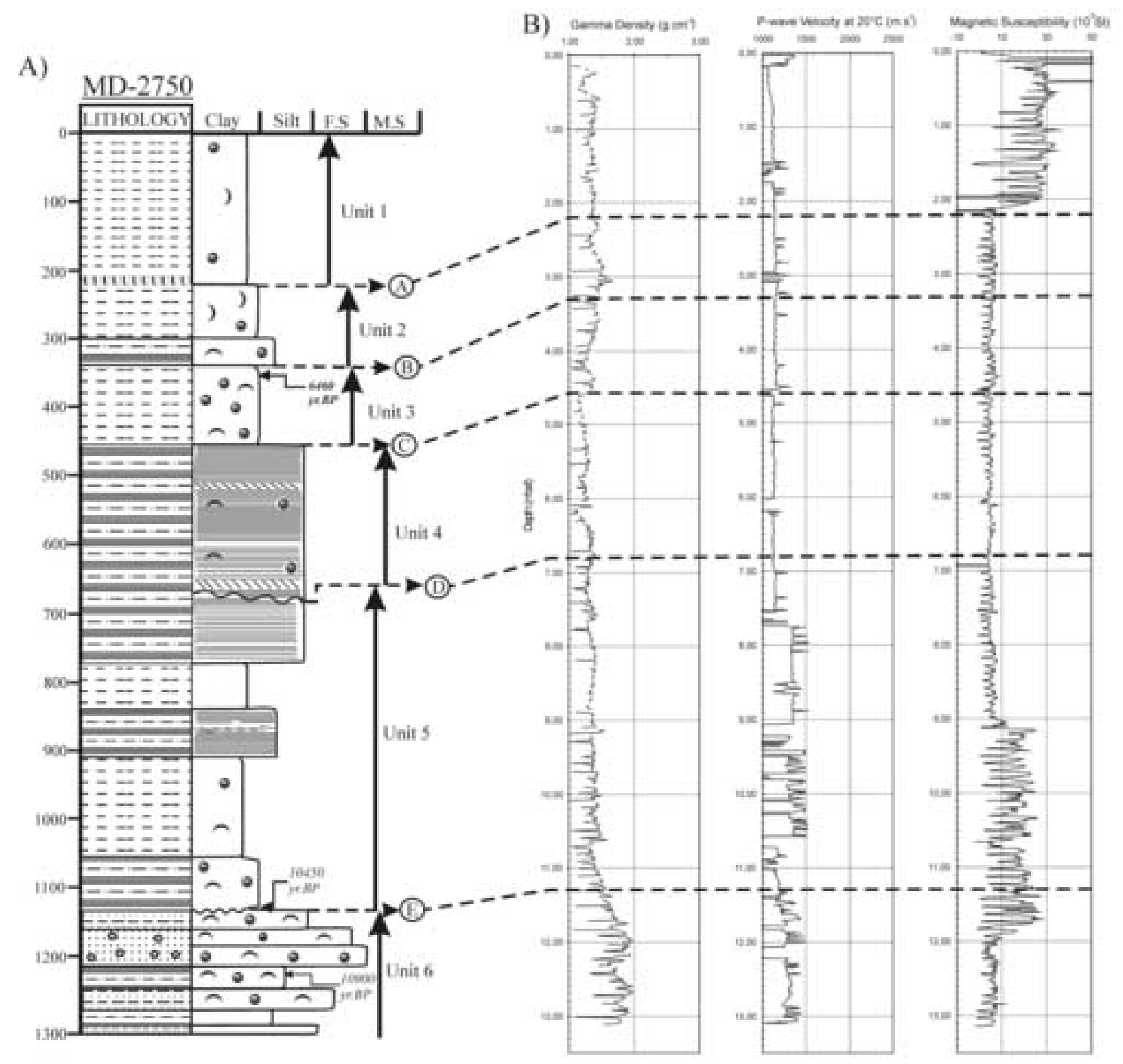

Figure 9 
Figure 10
Click here to download high resolution image

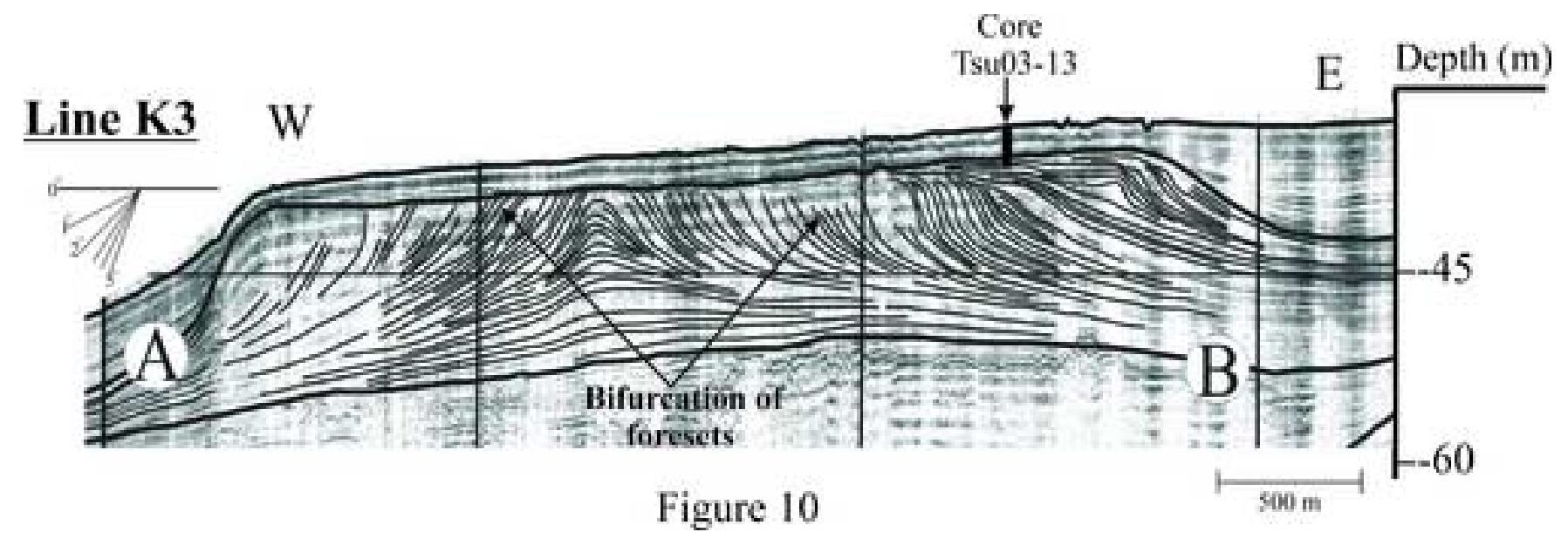

Figure 10 


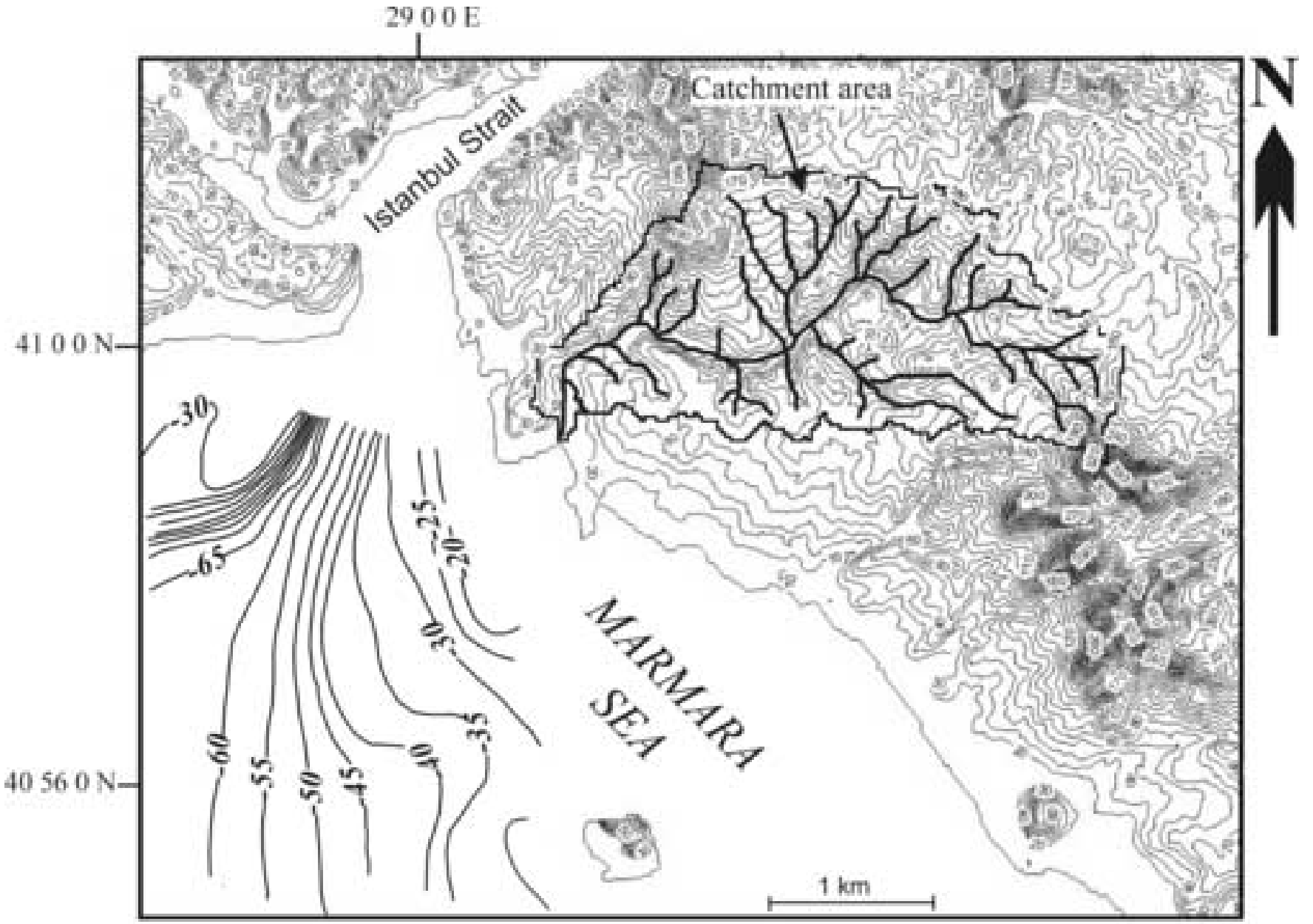

Figure 11 
This study

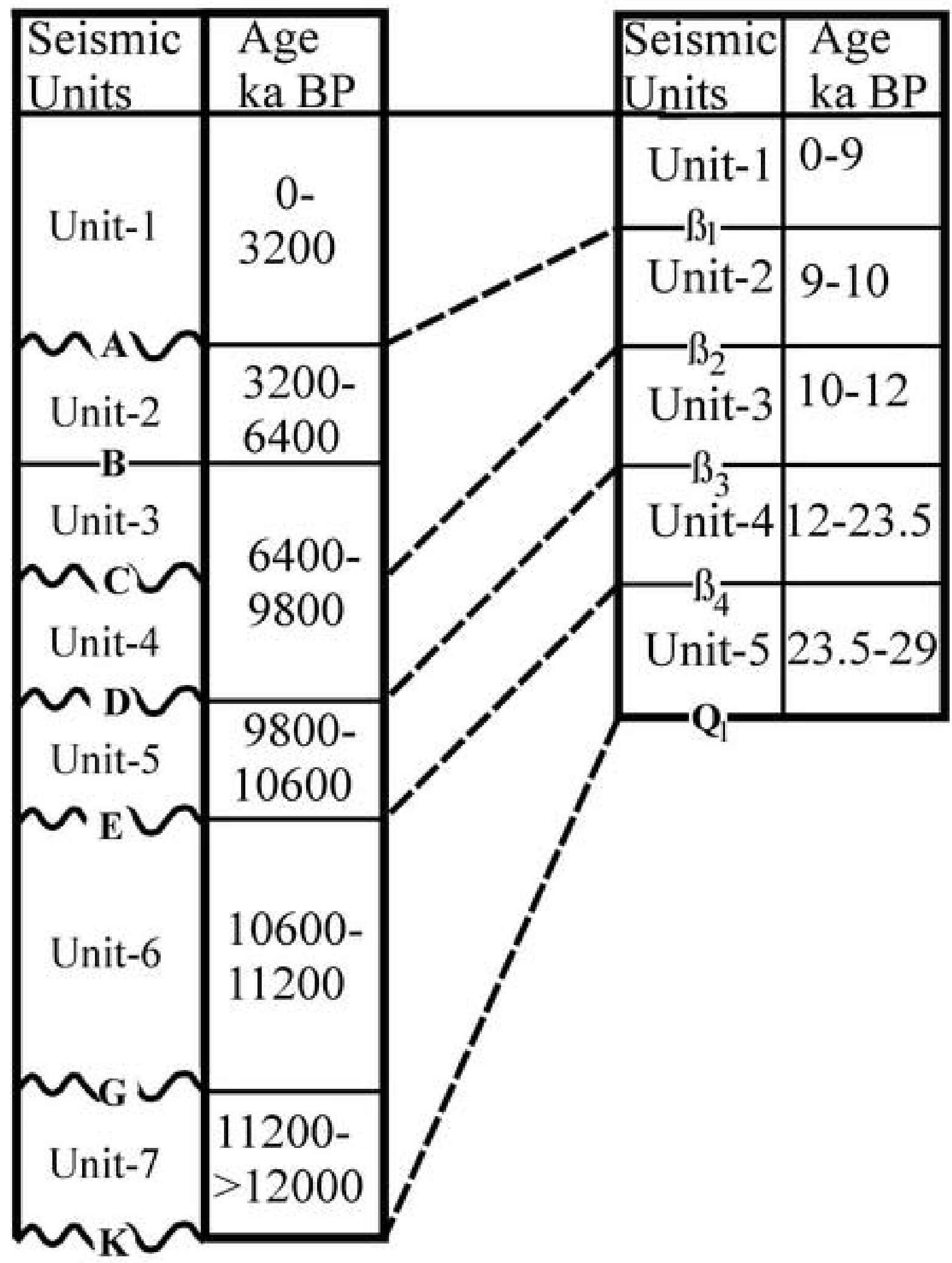

Figure 12

Hiscott et al. 2002

Seismic Age Units ka BP

Unit-1 $0-9$

Unit-2 9-10

Unit-3 $10-12$

Unit-4 12-23.5

Unit-5 23.5-29 


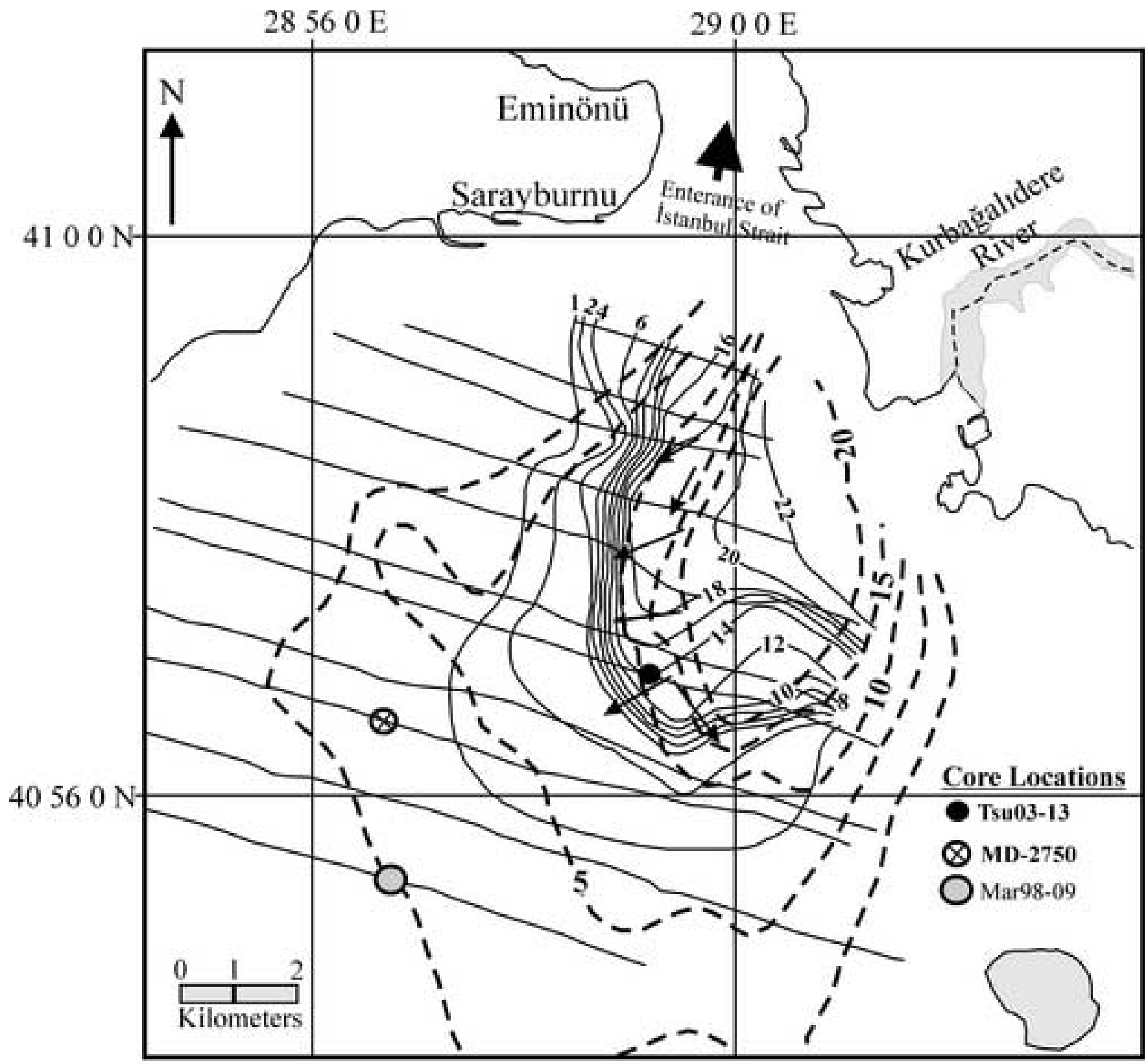

Figure 13 


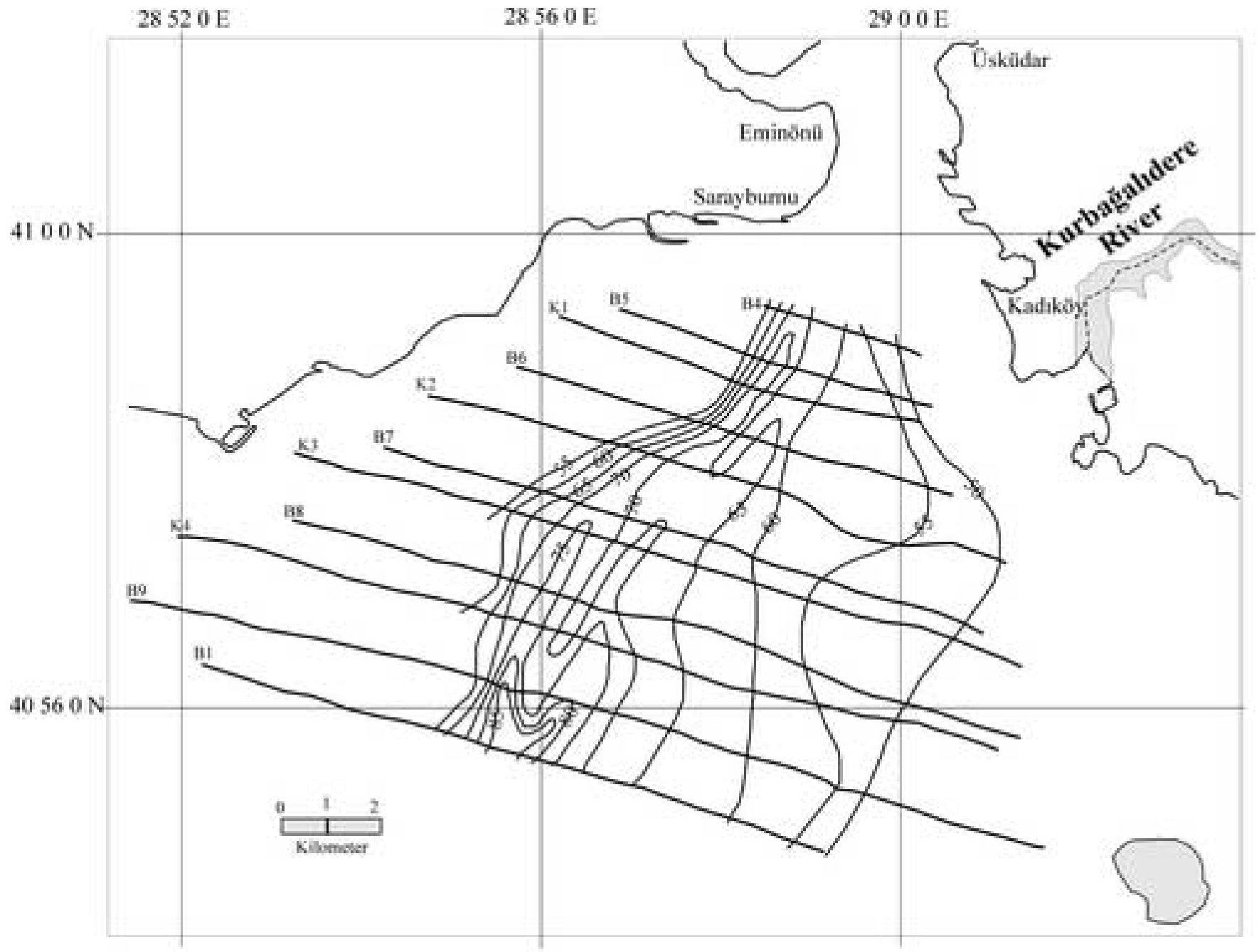

Figure 14 


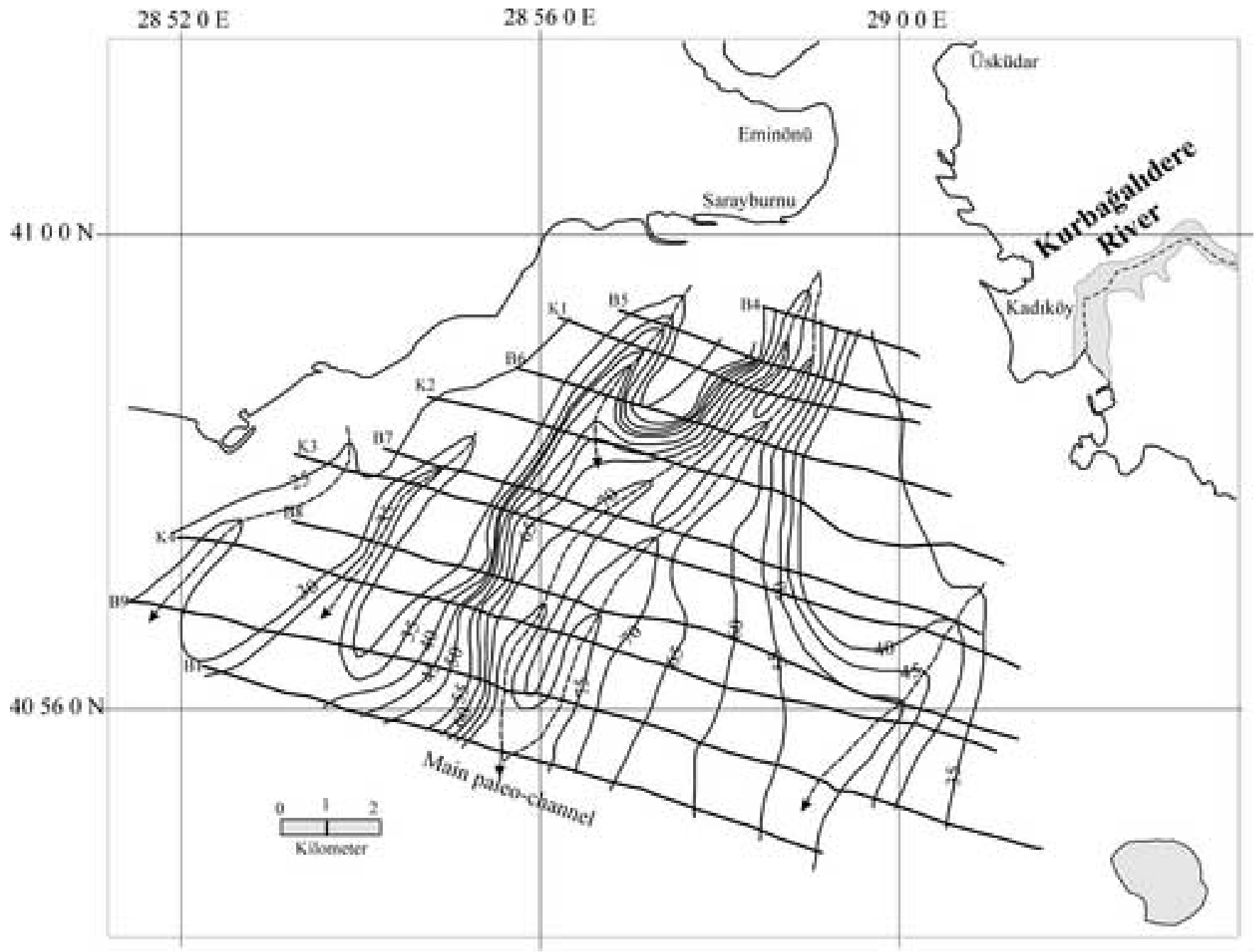

Figure 15 


\section{Table 1}

Conventional dates in gravity cores recovered fort his study (mbs, meter below surface; mbsf, meter below sea floor)

\begin{tabular}{|l|l|l|l|}
\hline $\begin{array}{l}\text { Site, location, water depth (mbs), dated } \\
\text { material (lab.number) }\end{array}$ & Unit & Core depth & Age $\left({ }^{\mathbf{1 4} C \text { yr BP.) }}\right.$ \\
\hline $\begin{array}{l}\text { Southern enterance to the Istanbul strait, } \\
\text { Tsu03-13,-34m, mollusc (A-13668) }\end{array}$ & Unit 2 & $1.55 \mathrm{mbsf}$ & $4380(+100 /-95)$ \\
\hline $\begin{array}{l}\text { Southern enterance to the İstanbul Strait, } \\
\text { MD-2750, -68m, bivalve (OS- 50131) }\end{array}$ & Unit 3 & $3.56 \mathrm{mbsf}$ & $6460+/-55$ \\
\hline $\begin{array}{l}\text { Southern enterance to the İstanbul Strait, } \\
\text { MD-2750, -68m, bivalve (OS- 53538) }\end{array}$ & Unit 5 & $11.26 \mathrm{mbsf}$ & $10450+/-50$ \\
\hline $\begin{array}{l}\text { Southern enterance to the İstanbul Strait, } \\
\text { MD-2750,-68m, bivalve (OS- 50130) }\end{array}$ & Unit 6 & $12.36 \mathrm{mbsf}$ & $10900+/-65$ \\
\hline
\end{tabular}


Table 2. Mean discharge and suspended sediment discharge rates of rivers around Marmara and western Black Sea regions.

\begin{tabular}{|l|l|l|}
\hline \multicolumn{1}{|c|}{ Rivers } & $\begin{array}{l}\text { Mean Discharge } \\
\left(\mathbf{m}^{3 / y r}\right)\end{array}$ & $\begin{array}{l}\text { Suspended Sediment } \\
\text { Discharge (t/yr) }\end{array}$ \\
\hline Gönen River & $477 \times 10^{6}$ & 188000 \\
\hline Devrenkani River & $227 \times 10^{6}$ & 177760 \\
\hline Kocaçay River & $633 \times 10^{6}$ & 375000 \\
\hline Soğanlı River & $864 \times 10^{6}$ & 1210000 \\
\hline Karasu River & $142 \times 10^{6}$ & 82000 \\
\hline Boluçayı River & $251 \times 10^{6}$ & 140000 \\
\hline Kurbağalıdere River & $80 \times 10^{6}$ & 60000 \\
\hline
\end{tabular}

